Ved Nils Retterstøl

Statens helsetilsyn har $i$ sin skriftserie (1-96) utgitt en oversikt over Bærumsmodellen og det arbeid som der er utført giennom en tiårs periode. Denne rapporten om Bærumsmodellen er utarbeidet av en arbeidsgruppe med ledende sosionom ved Bærum sykehus, Wenche Haukø, som leder. Den er gitt ut som en publikasjon under Handlingsplan mot selvmord. Rapporten har til hensikt å gi informasjon til den administrative og politiske ledelse $i$ kommuner og fylkeskommuner om hvordan det selvmordsforebyggende arbeid kan organiseres. Rapporten er også tenkt å være en inspirator til fagfolk som arbeider med selvmordsproblematikk.

Da Bærumsmodellen har spilt en ganske sentral rolle for opplegg av selvmordsforebyggende arbeid i Norge, både på fylkesplan og kommunalt plan, og ikke minst i sykehus, vil det være av interesse for de fleste som arbeider innenfor dette området å bli kjent med modellen. Flere steder i landet arbeider man med å få retningslinjer etter tilsvarende modeller, og der er også utarbeidet andre modeller.

Ved Bærum sykehus behandles det årlig vel 200 pasienter etter selvmordsfors $\varnothing \mathrm{k}$. Fra 1984 har det eksistert et fast og forpliktende samarbeid mellom Bærum sykehus og kommunehelsetjenesten i Asker og Bærum kommuner om behandling og oppfølging av selvmordsfors $ø$ kere.

Bærum sykehus er lokalsykehus og eies av Akershus fylkeskommune. Det skal dekke sykehusbehovet for befolkningen i Asker og Bærum kommuner, til sammen ca 140000 innbyggere (43000 i Asker, 94000 i Bærum).

$30-40 \%$ av selvmordsfors $\varnothing$ kerne som behandles i Bærum sykehus blir henvist videre til helsesøster i kommunen for

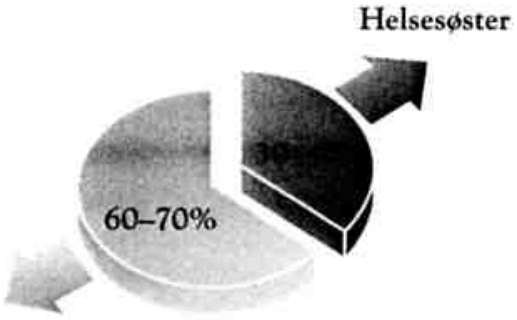

Annen behandling

oppfølging, mens de øvrige blir vist til annen behandling i første- eller andrelinjetjenesten.
Den tidligere avdelingsleder for sykehusets sosionomtjeneste, Kari Holten, påpekte allerede i 1978 den tilfeldige oppfølging selvmordsfors $\varnothing$ kerne fikk. I 1979 utarbeidet hun, i samarbeid med medisinsk avdeling, interne rutiner for psykososial behandling og oppfølging av disse pasientene. Alle innlagte ble henvist til sosionom for samtale.

Våren 1981 gjennomførte så en gruppe sosialhøgskolestudenter, etter Kari Holtens initiativ, et prosjekt om selvmordsfors $ø$ kernes behov for behandling og hvilke tilbud som fantes innenfor området Asker og Bærum.

Våren 1983 ble så et samarbeidsprosjekt mellom sykehuset og Bærum kommune etablert. Helsesøstrene fra kommunen skulle følge opp de aktuelle pasienter hjemme. Fra 01.01.84 har så dette samarbeidet omfattet også Asker kommune.

Det er den måten å organisere det selvmordsforebyggende team på, som har fătt navnet Bærumsmodellen.

En utfordring i det tverretatlige samarbeidet har vært de juridiske forhold, spesielt bestemmelsene om taushetsplikten. I samarbeid profesjonene imellom er sykehuspersonalets taushetsplikt opphevet ved skriftlig samtykke fra pasienten. Til det formålet er det utarbeidet et standard informasjonsskriv.

Bærumsmodellen består av tre trinn:

1. Den medisinske behandling og overvåking

\section{Psykososial/psykiatrisk intervensjon}

3. Oppfølging av helses $\varnothing$ ster
Det er utarbeidet skriftlige rutiner som definerer ansvars- og oppgavefordelingen internt, og som også regulerer det tverrfaglige samarbeide. Disse rutinene blir vurdert hvert annet år. Teamene består av psykiater og sosionomer fra sykehuset, helsesøster og psykolog fra Bærum kommune og helsesøster og psykiater fra Asker kommune.

Man har funnet ut at systematisk faglig veiledning er en forutsetning for å gå inn i denne typen arbeid. Arbeid med selvmordstruede bør bare være en del av team-medlemmenes arbeidsoppgaver, og det frarådes at noen jobber på heltid med selvmordsfors $\emptyset$ kere. I stedet anbefales eventuelt turnusordninger.

De fleste pasienter som kommer til Bærum sykehus etter selvmordsfors $\varnothing \mathrm{k}$, blir tatt hånd om i mottakelsen av medisinsk team. Intoksikasjon (selvpåført forgiftning) er vanligste innleggelsesårsak. Etter bestemmelsene i rutinene er det vakthavende lege i mottakelsesavdelingen som har ansvaret for en nøye vurdering av pasientens videre behov for behandling, blant annet om pasienten skal legges inn eller reise hjem.

Ved Bærum sykehus har sosionomene valgt å arbeide med selvmordsfors $ø$ kere ut fra en psykososial modell for sosialt arbeid. I kontakten med pasienten legges det vekt på en direkte og klar kommunikasjon. Det nyttes en intervjuguide i førstegangssamtalen med pasienten. Intervjuguiden bygger på et oppsett som er utarbeidet av Verdens Helseorganisasjon (European Parasui- 
cide Study Interview Schedule, EPSIS). Hensikten med dette er å gjøre en grundig kartlegging av omstendighetene rundt selvmordsfors $ø$ ket slik at sosionomen kan bli bedre i stand til å vurdere suicidalfare og behovet for videre behandling. Sosionomene samarbeider nært med den legen som er ansvarlig for posten.

Sykehusets rutiner for arbeidet med selvmordsfors $\emptyset$ kere definerer når pasienten skal henvises til psykiatrisk konsulent. Vedkommende konsulent er tilstede to dager pr uke. Psykiaterens tilnærming bygger på åpenhet som st $\varnothing$ ttende og ansvarliggjørende moment. Målsettingen med psykiaterens intervensjon er blant annet

- en diagnostisk vurdering,

- vurdering av behovet for behandling eller omsorg, eller

- vurdering for behovet for psykofarmakologisk intervensjon

Sentralt $\mathrm{i}$ intervensjonen står naturligvis forsøk på å få pasienten til å se at det finnes andre alternativer til det å ta sitt liv. Det er psykiateren som har veiledningsansvaret $\mathrm{i}$ teamene.

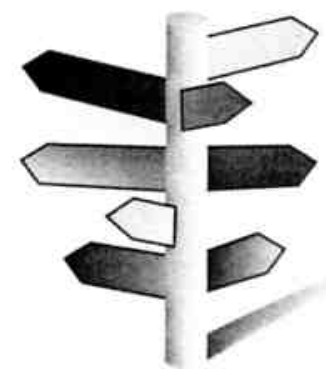

Helsesøster har så ansvaret for det oppsøkende arbeidet når pasienten er kommet hjem. Målgruppen er ikke bare pasienter som er behandlet ved sykehuset, men også pasienter som er behandlet ved legevakten og selvmordstruede som tar direkte kontakt med det kommunale teamet.

Helsesøsters intervensjon er på mange måter å fungere som et slags "ombud" for den selvmordstruede, og en person som skal sørge for at tiltak blir iverksatt for å skape en forandring til beste for pasienten. Helsesøstrene arbeider også med å aktivisere pasientens sosiale nettverk, og fortsetter den motivering for behandling som ble startet i sykehuset.

Helsesøstrene deltar også i primærforebyggende arbeid i skolene, og ellers $\mathrm{i}$ informasjons- og opplæringsarbeid $\mathrm{i}$

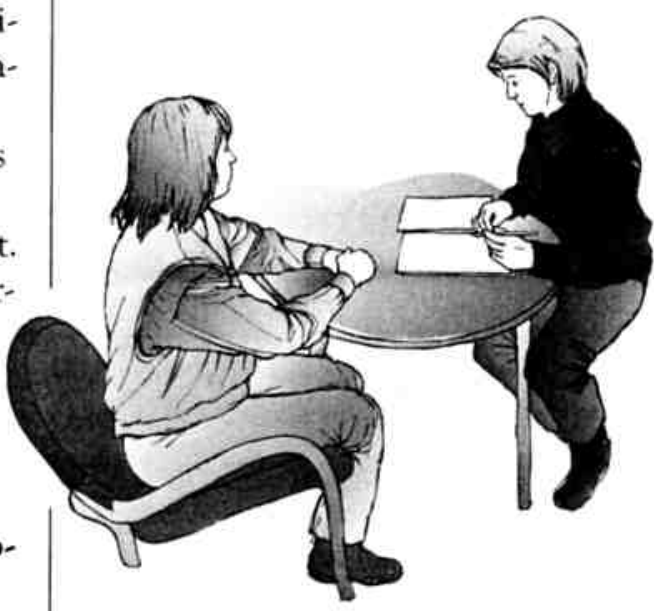

samarbeid med team-medlemmene fra sykehuset.

Det presiseres at de forskjellige faggruppene i teamene er skolert $\mathrm{i}$ å jobbe etter ulike tilnærmingsmåter.

De erfaringer man hittil har høstet tyder på at et differensiert tilbud er viktig, og det er også viktig med et velutviklet veiledningsapparat. I Bærumsmodellen har man tro på prosjektet, og regner med at andre vil nyttiggjøre seg deres erfaring.

Som det allerede er nevnt, er man mange steder i vårt land i sving med å utvikle modeller som representerer modifikasjoner av Bærumsmodellen.

Denne publikasjonen er på 49 sider, den er lettlest og vil sikkert være til nytte for det selvmordsforebyggende arbeid $\mathrm{i}$ vårt land.

Referanse: Bærumsmodellen 1984-1994. Skriftserie 1-96. Statens helsetilsyn.

Denne rapporten kan man få ved henvendelse til Statens helsetilsyn, $\mathrm{Pb} 8128$ Dep, 0032 Oslo, telefon: 22248888 .

\section{Referat fra forste mote i Forebyggingsforum 24. okt. 1996}

En utfordring i det selvmordsforebyggende arbeidet er å knytte kontakt både mellom forsknings- og praksisfeltet og mellom de ulike forebyggingsprosjektene. Seksjon for selvmordsforskning og -forebygging ved Universitetet i Oslo har forsøkt å møte denne utfordringen ved å etablere et Forebyggingsforum for helseregion $I \mathrm{og}$ II. Dette forum er tenkt som en møteplass hvor man kan utveksle ideer og erfaringer fra ulike forebyggingsprosjekter, få belyst forskning av særlig relevans for praksisfeltet og drøftet praktiske og jordnære problemstillinger i tilknytning til det forebyggende arbeidet.

Det først møtet i dette forum ble holdt den 24. oktober på Stefan-hotellet i Oslo. Foruten presentasjon av deltakerne og av Seksjon for selvmordsforskning og -forebygging, hadde vi tre temaer på programmet

1) Registrering og oppfølging av selv. mordsfors $\phi$ kere, innledning $\mathrm{v} /$ prosjektleder Nils Petter Reinholdt

2) Strategier for kompetanseoppbygging, innledn. v/undervisn.leder Astrid Dahl

3) Oppfølging av etterlatte etter selvmord, innledning $v /$ sosionom Tone Conradi og pedagog Solveig Krogsrud.

Det var satt av $1 / 2$ time til innledning for hvert av emnene og $1 / 2$ time til diskusjon. Interessen var stor. Et deltakerantall på 50 personer var langt større enn hva vi på forhånd hadde regnet med. Og evalueringen ga entydig uttrykk for at et slikt forum dekket et behov for "påfyll" og inspirasjon. Alle foreleserne ga gode og praksisnære bidrag, men siden dagen ikke var planlagt med tanke på så stor deltakelse, ble tiden for knapp til samtale og utveksling av erfaringer. Det ble uttrykt ønske om at vi i kommende møter konsentrerer tiden om ett tema per gang, og at vi i neste møte, som vil bli holdt i april/mai 1997, tar for oss formidling. Dette forum er ment for alle som ønsker mer kontakt med andre innen praktisk, selvmordsforebyggende arbeid. Gi beskjed til vår seksjon ved sekretær Trine Myrvang, om du foreløpig ikke står på adresselisten, men ønsker å få tilsendt informasjon om tidspunkt og program for neste møte.

Mette Ystgaard 